\title{
İskelet displazilerinde kalça patolojilerinin değerlendirilmesi
}

\author{
Evaluation of hip pathology in the skeletal dysplasias
}

\author{
Güney Yılmaz \\ Hacettepe Üniversitesi Tıp Fakültesi Hastanesi, Ortopedi ve Travmatoloji Anabilim Dalı, Ankara
}

\begin{abstract}
İskelet displazilerinde, metafizyel ve epifizyel gelişim bozuklukluklarına bağlı olarak, eklem çevrelerinde farklı deformiteler ortaya çıkabilir. Bu gelişim bozukluklarının ve deformitelerin en sık görüldüğü bölgelerden birisi de kalça eklemidir. Proksimal femur epifizindeki kemikleşme gecikmesi, büyüme plağındaki düzensizlikler femur başının yassılaşmasına ve femur boyun - cisim arasındaki ilişkinin bozulmasına neden olur. Femur başındaki düzleşmeyi, laterale taşma, subluksasyon ve farklı tipte proksimal femur deformiteleri takip edebilir. Proksimal femurda ortaya çıkan iki temel deformite femur boyun cisim açısının arttığı koksa valga ve azaldığı koksa vara deformiteleridir. Koksa valga ve yetersiz asetabulum gelişimine femur başı subluksasyonu eşlik eder. Kalça displazisi erken dönemde ağrı ve hareket kısıtlılığı ile sonuçlanır. Koksa vara deformitesi femur boyun ve cismi arasındaki açının $110^{\circ}$ 'nin altında olması ile karakterizedir; bu durum, kalça hareketlerinde kısıtlılığa ve yürüme güçlüğüne neden olarak günlük yaşamı olumsuz etkileyebilir. Kalça displazisi ve koksa vara deformitesinin her ikisi de asetabulum ve proksimal femuru ilgilendiren farklı osteotomi teknikleriyle düzeltilebilir. Her iki patolojinin de uygun yapılan tedavilere rağmen erken kalça artriti ile sonuçlanabileceği ve hastaların total kalça artroplastisine ihtiyaç duyabilecekleri akılda tutulmalıdır.
\end{abstract}

Anahtar sözcükler: iskelet displazisi; kalça displazisi; koksa vara
In skeletal dysplasia, various types or deformities may develop around the joints due to metaphyseal and epiphyseal growth disturbances. One of the most common location of these growth disturbances and deformities is the hip joint. The delay in ossification of the proximal femur epiphysis and growth plate abnormalities can cause femoral head flattening and violate the relationship between the femoral neck and the shaft. Femoral head flattening may be followed by lateral subluxation and different types of proximal femur deformities. The two main deformities emerging in the proximal femur are the coxa vara and the coxa valga in which the femoral neck and shaft angle is decreased and increased, respectively. Coxa valga and failure of acetabular development is accompanied by femoral head subluxation. The hip dysplasia results in hip pain and limited range of motion in the early period. The coxa vara deformity is characterized by a femoral neck - shaft angle less than $110^{\circ}$. This can limit the hip motion and cause walking difficulties which disturb the daily activities. Both the hip dysplasia and coxa vara deformity can be corrected by utilizing different osteotomy techniques in the acetabulum and the proximal femur. It should be kept in mind that both pathologies related to hip may end up with early hip arthritis, and total hip arthroplasty may eventually be necessary for these patients despite a properly applied hip reconstruction.

Key words: skeletal dysplasia; hip dysplasia; coxa vara
(1)

skelet displazilerinde, kıkırdak metabolizması patolojileri ve mevcut kıkırdak yapının gecikmiş kemikleşme nedeniyle mekanik olarak yeteri kadar desteklenememesi sonucu, eklem çevrelerinde farklı deformiteler ortaya çıkabilir. Bu gelişim bozukluklarının ve deformitelerin en sık görüldüğü bölgelerden birisi de kalça eklemidir. ${ }^{[1]}$

Epifizyel tutulumun ağır bastığı displazilerde (psödoakondroplazi, diastrofik displazi, multipl epifizyel displazi, spondiloepifizyel displazi, mukopolisakkoridozlar) kıkırdak femur başı, üzerine yük binmesiyle beraber erken çocukluk döneminde deformasyona uğrar. Proksimal femur epifizindeki kemikleşme gecikmesi ve büyüme plağındaki düzensizlikler, femur başının genişlemesine neden olur. Kalça ekleminin artrografik değerlendirmesinde, femur başının şeklinin mantar şeklini aldığı görülebilir. ${ }^{[2,3]}$ Femur başındaki düzleşmeyi, laterale taşma, subluksasyon ve farklı tipte proksimal

- Iletişim adresi: Doç. Dr. Güney Yılmaz, Hacettepe Üniversitesi Tıp Fakültesi Hastanesi, Ortopedi ve Travmatoloji Anabilim Dalı, Sıhhiye, Ankara Tel: 0312 - 3051209 e-posta: guney.yilmaz@hacettepe.edu.tr

- Geliş tarihi: 8 Ağustos 2016 Kabul tarihi: 8 Ağustos 2016 
femur deformiteleri takip edebilir. ${ }^{[4]}$ Proksimal femurda ortaya çıkan iki temel deformite, femur boyun - cisim açısının arttığı koksa valga ve azaldığı koksa vara deformiteleridir. Koksa vara deformitesinin görüldüğü iskelet displazilerinde temel sorun, kalça eklem instabilitesinden ziyade, kalça eklem biyomekaniğinin ve uyumunun bozulmasına ikincil ortaya çıkan belirti ve bulgulardır. Koksa valga deformitesi ise, çoğu zaman eşlik eden femur başı düzleşmesi ve laterale taşma nedeniyle, asetabulum gelişim bozukluklarını (asetabular displazi) tetiklerve uzun dönemde dejeneratif kalça sorunlarına kapı aralar.

Metafizyel etkilenimin ağır bastı̆̆ı displazilerde, asetabulumun gelişimi ve morfolojik yapısı çoğu zaman normal ya da hafif displaziktir. Buna karşın, femur boynunda parçalanma, kısalık, femur boynunun ortaya çıkışında gecikme görülebilecek patolojilerdendir. ${ }^{[2]}$

Bu bölümde, her iskelet displazisini kalça yönünden ayrı ayrı tartışmak yerine, iskelet displazili hastalarda karşılaşılan temel sorunlar üzerinden bir anlatım gerçekleştirilecektir. Bu sorunların ilkini koksa valga deformitesinin ve asetabulum gelişim yetersizliğinin bereber görüldüğü "kalça displazisi" bölümü oluşturur. Üzerinde durulacak diğer bir sorun, femur boyun cisim açısının $110^{\circ}$ 'nin altına indiği ve asetabular gelişim bozukluklarıyla beraber farklı klinik sorunların eşlik ettiği "koksa vara" olacaktır. Son olarak, iskelet displazili hastaların bir bölümünde kaçınılmaz olarak gelişen dejeneratif kalça hastalığında kalça protezi uygulaması üzerinde durulacaktır.

\section{KALÇA DisPLAZisi}

Özellikle epifizyel tutulum ile seyreden iskelet displazilerinde kalça ekleminde karşılaşılan temel sorunların başında kalça displazisi gelmektedir. Çoğu zaman karşılaşılan tablo, disloke olmuş ve açık redüksiyona ihtiyaç duyan bir kalçadan ziyade, koksa valga, femur başı subluksasyonu ve asetabular displazinin beraber seyrettiği bir patolojidir. İskelet displazilerinde görülen kalça displazisinin tedavisi konusunda literatürde en geniş yer tutan hasta grubu, değişik tiplerdeki mukopolisakkoridozlar (MPS) ve multipl epifizyel displazidir.

MPS'ler, glikozaminoglikan (GAG) yıkım basamaklarındaki enzim yetmezlikleri sonucu gelişen bozukluklardır. GAG birikiminin büyüme plağındaki uyarı ve kontrol mekanizmalarını bozması sonucu kemik deformitelerine neden olması çok muhtemeldir. ${ }^{[1]}$ Hematopoietik kök hücre nakli ve düzenli enzim tedavisi ile, MPS hastalarında beklenen yaşam süresi uzar ve hayat kalitesi artar. $^{[5]}$ Fakat, dolaşımdaki enzimin kas iskelet sistemi penetrasyonu yetersizdir. Bu nedenle, iskelet sistemine ait patolojiler görülmeye devam eder. ${ }^{[6]}$ MPS'lerde enkondral ve membranöz kemik gelişiminin bozulması, asetabulumun özellikle anterior ve superiorunda yetmezlik meydana getirerek, displastik bir asetabulum görüntüsü oluşturur. ${ }^{[7]}$ Asetabulum çoğu zaman sığdır, kapasitesi yetersizdir ve femur başının subluksasyonuna izin verir (Şekil 1). Femur başında çökme, düzleşme, proksimal femur epifiz mediyalindeki gelişme kusuru ve femur boyun cisim açısının artışı, femur başı subluksasyonunu kolaylaştırıcı etki yapar. Gerçek asetabulum zamanla sığlaşır, femur başı örtünmesi gittikçe azalır ve yalancı asetabulum oluşumu gözlenebilir (Şekil 2).

MPS'lerin birçok alt tipinde (Tip I, II, III, IV ve VI) değişik oranlarda asetabular displazi görülür. Abduksiyon cihazı kullanımıyla ilgili literatürde bilgi yoktur; motor gelişimleri zaten yavaş olan bu hasta grubunda çocuğun hareket kapasitesini azaltacağı ve motor gelişime olumsuz etkisi olacağı için önerilmez. Bu tür kalçalarda cerrahi tedavinin amacı, uzun dönemde kalça artroplastisi gerekebileceğini de göz önüne alarak, proksimal femur ve asetabulum yapısına zarar vermeden subluksasyonu ve asetabular kapasiteyi düzeltmektir. Sadece Salter, Pemberton gibi pelvik osteotomiler ya da izole proksimal femur varus osteotomilerinin, femur başının kapsanmasında yetersiz olacağı düşünülmektedir. Kennedy ve ark., 13 (26 kalça) MPS Tip I hastasında, proksimal femur varus ve Salter osteotomisini birlikte kullanarak tatminkar bir femurbaşı örtünmesi sağladıklarını belirtmişlerdir. Kalça displazisinde belirgin düzelme sağlamalarına rağmen, 26 kalçanın 15'inde erken osteoartrit geliştiğini bildirmişlerdir. ${ }^{[8]}$ Yapılan bir başka çalışmada takip edilen 51 Hurler sendromlu (MPS Tip I) hastanın 102 kalçasının tümünde kalça displazisinin görüldügü belirtilmiştir. Bu çalışmada, 40 kalçaya uygulanan cerrahi tedavinin sonuçları sunulmuştur. Ortalama yaşları 6,8 olan bu hasta grubunda; 10 kalçada yalnız proksimal femur varus osteotomisi, 30 hastada ise femoral varus ve pelvik osteotomi (Pemberton, Shelf ya da Dega) kombinasyonu uygulanmıştır. ${ }^{[9]}$ Ortalama 5,4 yıllık takipte, çalışmacılar asetabular indeks, merkez kenar açısı ve femur boyun cisim açılarında belirgin düzelme elde ettiklerini bildirmişlerdir. Cerrahi uygulanmayan grupla karşılaştırıldığında, cerrahi uygulanan grupta radyolojik bulguların, femur başı örtünmesi ve femur boyun cisim açısı bakımından anlamlı olarak daha iyi olduğu gösterilmiştir. Koksa valga ve asetabular displazinin birlikte seyrettiği bu hasta grubunda proksimal femurda uygulanan varus derotasyon osteotomisinin amacı, femur başını asetabulum içine yönlendirerek eklem uyumunu arttırmak ve asetabulum gelişimini tetiklemektir. Bu çalışmanın önemli sonuçlarından bir tanesi, sadece proksimal femurda varus derotasyon osteotomisi yapılan 


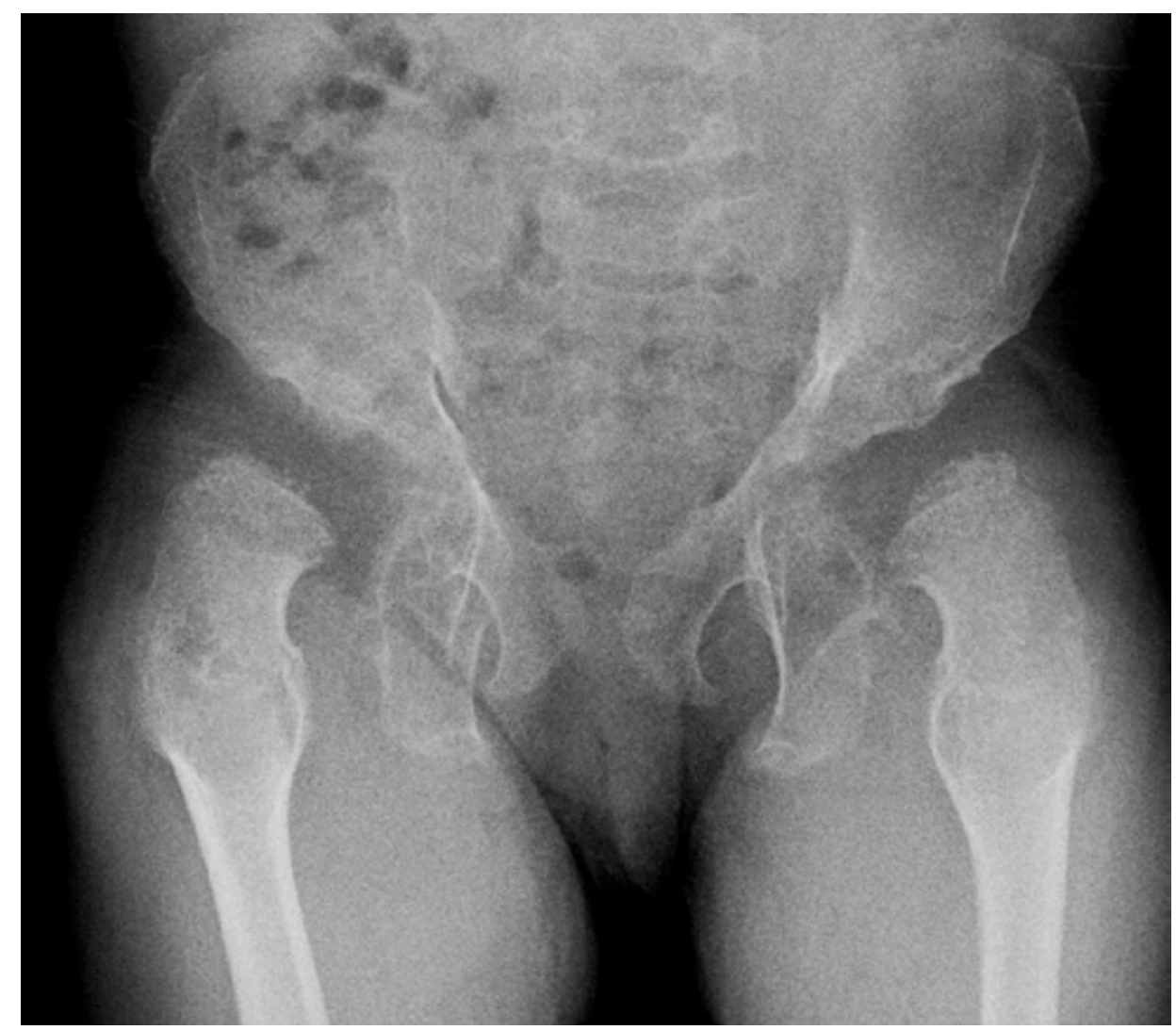

Şekil 1. Dokuz yaşında kız hasta. Morquio sendromu. Belirgin kalça displazisi, femur başı kemikleşmesinde gecikme ve femur başı subluksasyonu görülmekte.

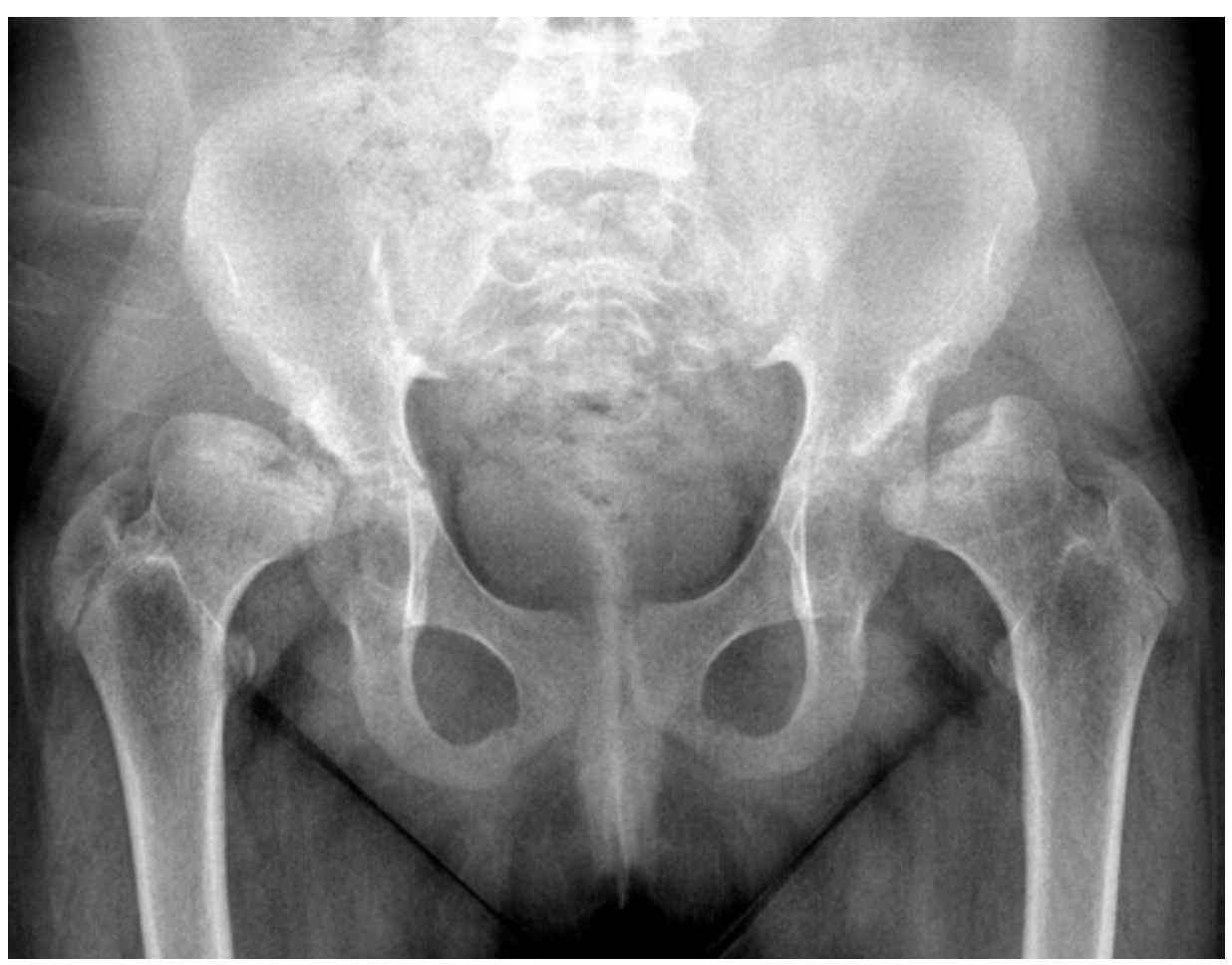

Şekil 2. On iki yaşında kız hasta. MPS Tip VII. Kalça subluksasyonunun ileri döneminde yalancı asetabulumun oluşmaya başladığı görülmekte. 


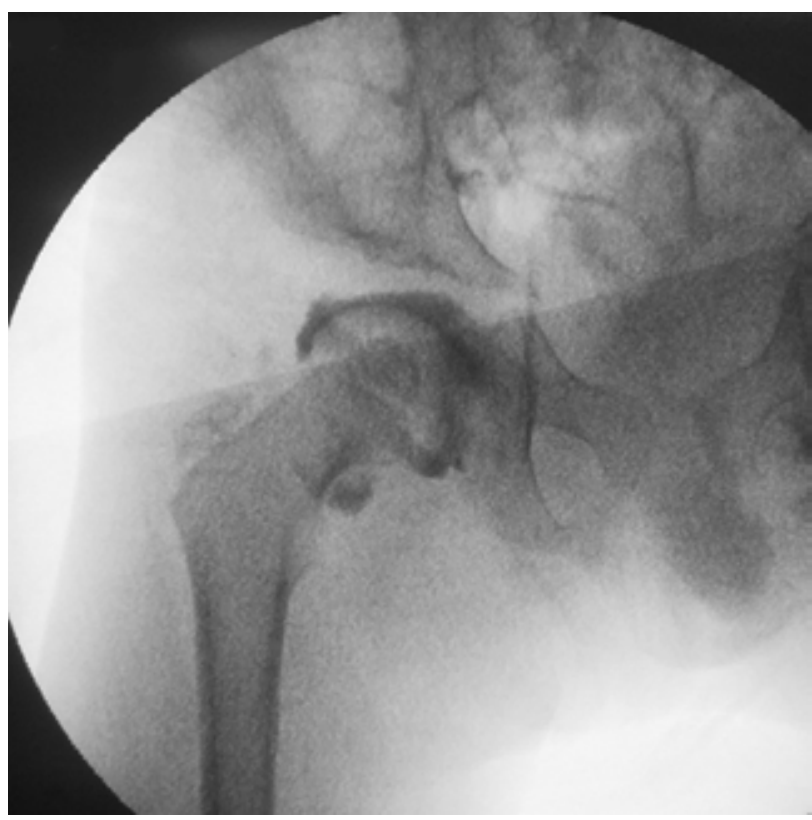

Şekil 3. Beş yaşında erkek hasta. Morquio sendromu. Alt ekstremite deformitelerine yönelik yapılan cerrahi sırasında elde edilen sağ kalça artrografisinde kıkırdak tavanın gelişiminin iyi olduğu görülmekte.

10 kalçada asetabulum gelişiminin tatminkar düzeyde olmadığının ortaya konmuş olmasıdır. ${ }^{[9]}$ Bu bulguyu destekler şekilde Field ve ark., yapılan artrografilerde asetabulum kıkırdak tavanının oluşumunda bir yetersizlik görülmediğini, fakat yapılan varus osteotomisi sonrasında kıkırdak tavanda beklenen kemikleşmenin olmadığı ve baş örtünmesindeki yetersizliğin devam ettiğini belirtmişlerdir (Şekil 3). ${ }^{[10]}$ Bu hasta grubundaki asetabular displazi tedavisinde, femoral girişime ek olarak pelvik bölgeyi hedefleyen cerrahi yöntemlerin de (Dega, Pemberton, Salter) tedavinin bir parçası olması gerektiği kabul edilmektedir. Hangi pelvik osteotominin uygulanması gerektiği konusunda fikir birliği yoktur. ${ }^{[9,10]}$ Dhawale ve ark., Pemberton ya da Salter osteotomisinin tek başına ya da femoral varus osteotomisi ile beraber uygulandığı MPS hastalarında, femur başındaki örtünme sorununun ve subluksasyonun devam ettiğini ve bu hastaların takiplerde şelf asetabuloplasti ile revize edildiğini bildirmişlerdir. Buna karşın varus osteotomisi ve şelf asetabuloplastisinin beraber uygulandığı hastalarda sonuçların iyi olduğunu belirtmektedirler. ${ }^{[11]}$ Femur başı örtünmesi için uygulanabilecek diğer bir yöntem üçlü pelvik osteotomidir. Literatürde bu yöntem hakkında yeterli veri bulunmamaktadır. Spooner ve ark., Çekçe yayımladıkları bir makalede, multipl epifizyel displazisi olan üç hastada (dört kalça) uyguladıkları Steel osteotomisi sonuçlarının iyi olduğunu belirtmişlerdir (Şekil 4). ${ }^{[12]}$
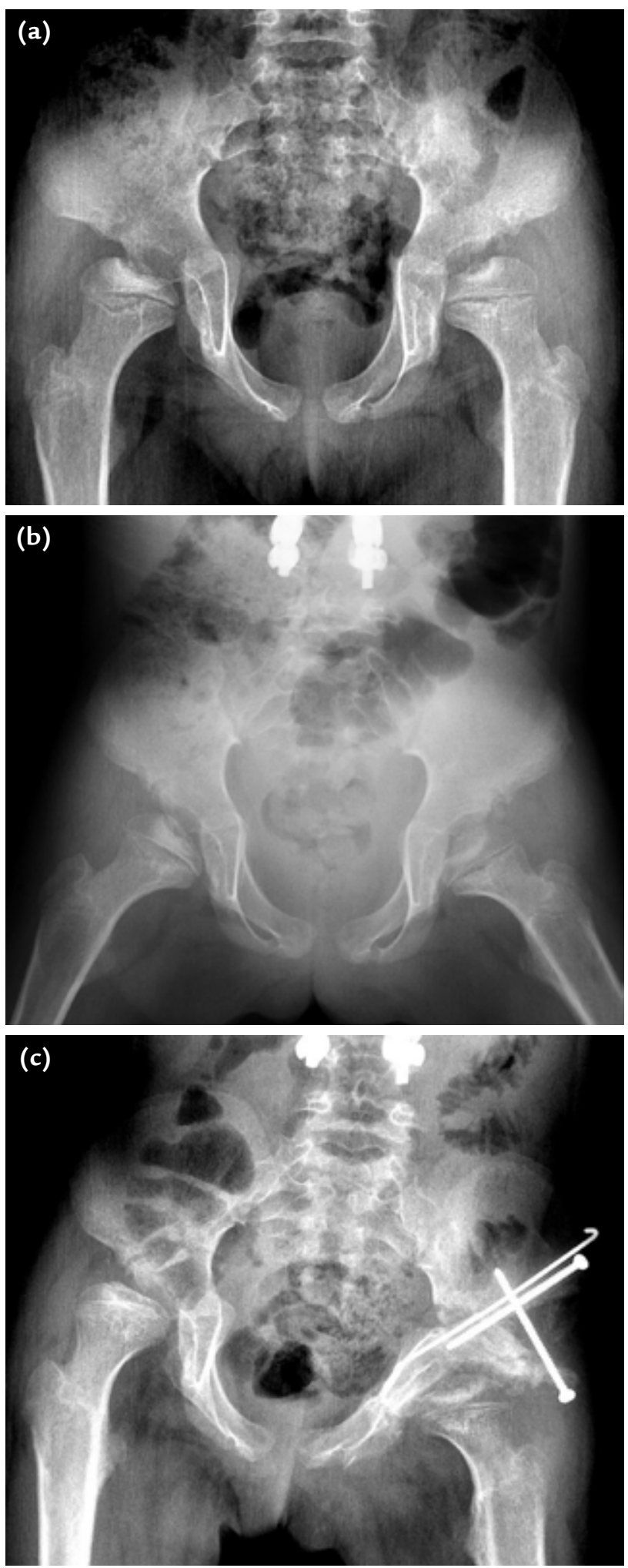

Şekil 4. a-c. Dokuz yaşında kız hasta. MPS Tip VI. Nötral önarka pelvis grafisinde asetabular displazi ve femur başındaki örtünme yetersizliği görülmekte (a). Abduksiyon grafisinde her iki femur başı ve asetabulumun uyumu görülmekte (b). Üçlü pelvik osteotomi uygulanarak elde edilen femur başı örtünmesi, 2. ay takip grafisi (c). 
Bu hasta grubunda radyolojik olarak iyi sonuç veren yöntemlerin, uzun dönemde klinik olarak iyi sonuçlar vermeyebileceği akılda tutulmalı ve hasta/yakınları gelecekte karşılaşılabilecek kalça sorunları ile ilgili bilgilendirilmelidir.

\section{KOKSA VARA}

Koksa vara, femur boyun cisim açısının $110^{\circ}$ veya altında olması olarak tanımlanır. Yenidoğan döneminde $150^{\circ}$ civarındaki bu açı, büyümeyle azalır ve erişkin dönemde yaklaşık $125^{\circ}$ 'ye iner. Proksimal femur gelişimi ve matür şeklinin oluşumu, trokanter major ve femur boynunun gelişimi ile gerçekleşir. Kas kuvvetleri, yer çekimi etkisi ve yürüme sırasında ortaya çıkan karşılıklı kuvvetler de femur boynu ve cismi arasında oluşan açısal gelişimde etkilidir. ${ }^{[13,14]}$

Koksa vara deformitesi, farklı iskelet sistemi hastalıklarıyla birlikte görülebileceği gibi, izole olarak da karşımıza çıkabilir. Genel kabul görmüş bir sınıflandırma olmasa da, Günther ve ark. tarafından önerilen sınıflandırma oldukça kapsayıcıdır:

1. Doğumsal koksa vara (primer-gelişimsel-idiyopatik). Altta yatan ikincil bir klinik sorun olmadan ortaya çıkan deformite.

2. Farklı tipte iskelet displazileri (epifizyel-metafizyel) ile birlikte görülen koksa vara.

3. Kalçada şekil bozukluklarına neden olan hastaIıklara (enfeksiyon, avasküler nekroz, travma, tümörler, Legg-Calvé-Perthes hastalı̆̆ı vb.) ikincil ortaya çıkan koksa vara.

4. Sistemik osteopeni (rikets, osteogenesis imperfekta) ile birlikte seyreden koksa vara. ${ }^{[15]}$

Koksa vara deformitesi mevcut olan kalçalarda, femur başı hemen her zaman asetabulum merkezindedir ve eklem kararlıdır. Hastanın yaşadığı klinik sorunlar, varus deformitesinin kalça biyomekaniği üzerindeki olumsuz etkileri sonucu ortaya çıkar. Femur boynundaki kısalık ve trokanter majorun proksimale yer değiştirmesi, abduktor kolda kısalma, yürüme sırasında aksama ve abduksiyon kısıtlılı̆̆na yol açar. İskelet displazisi zemininde ortaya çıkan koksa vara deformitesine çoğu zaman kalça ekleminde fleksiyon kontraktürü ve lomber lordoz da artış eşlik eder. Uzun dönemde ise kalça artriti gelişme riski yüksektir.

Proksimal femur büyüme plağının (PFBP) direncinin, bükülme ve makaslama kuvvetlerine karşı düşük, buna karşın kompresif kuvvetlere karşı daha yüksek olduğu bilinmektedir. Pauwels, koksa vara deformitesinin düzeltilmesinde büyüme plağının yöneliminin düzeltilmesinin en önemli basamaklardan biri olduğunu belirtmiştir. PFBP'nin horizontal pozisyona getirilmesi, varus pozisyonuyla ortaya çıkan makaslama kuvvetlerini kompresif kuvvetlere çevirir ve deformitenin tekrarlama riskini azaltır. Yetersiz düzeltme sonrası, makaslama kuvvetlerinin etkin olduğu büyüme plağında varus deformitesinin tekrarlama riski yüksektir. ${ }^{[16]} \mathrm{Bu}$ konudaki temel bilgiler daha çok doğumsal koksa vara literatürüne dayanmakla beraber, iskelet displazilerinde ortaya çıkan koksa vara deformitesi de benzer biyomekanik prensipler üzerinden değerlendirilebilir ve tedaviyi bu prensipler yönlendirir.

Moez ve ark., iskelet displazilerinde görülen koksa vara olgularını inceledikleri çalışmalarında, bu hasta grubunda iki tip proksimal femur yapısıyla karşılaştıklarını belirtmişlerdir. ${ }^{[14]}$ Bir grup hastada femur başının parçalanmış bir görüntüye sahip olduğu görülmüştür. $\mathrm{Bu}$ hasta grubunda displazi, femur başı epifizini, kıkırdak yapıyı, büyüme plağını ve zaman zaman femur boynunu etkiler. Bu hasta grubunda femur boynu ve cismi arasındaki açısal ilişkiyi standart ölçümlerle ortaya koymak mümkün değildir. Yazarlar, bu hasta grubunda trokanter majorun asetabuluma göre yerleşimini göz önüne alan Hilgenreiner-trokanterik açıyı (Şekil 5a) kullanmışlardır. Diğer hasta grubunda, femur başı ve boynunda kemikleşme mevcuttur. Deformite, büyüme plağı ya da boyunda lokalize olabilir. Bu hasta grubunda; epifiz ve diyafiz arasındaki açı (epifiz-diyafiz açısı, EDA), femur boynu ve diyafiz arasındaki açı (boyun-diyafiz açısı, BDA) ya da epifiz ve horizontal düzlem arasındaki açı (Hilgenreiner-epifiz açısı, HEA) kullanılabilir. Direkt grafi ile sağlıklı görüntüleme elde edilememesi durumunda femur baş ve boynunu daha kaliteli ortaya koymak için seçilecek uygun yöntem, manyetik rezonans (MR) görüntülemedir (Şekil 5b).

Hastada klinik olarak, yürüyüş sırasında aksama (trendelenburg yürüyüşü), abduksiyon kısıtlılığının olması; radyolojik olarak da HEA'nın $60^{\circ}$ 'nin üstünde ya da BDA'nın $110^{\circ}$ 'nin altında olması; koksa vara deformitesinin ilerleyici olması, cerrahi tedavi endikasyonlarını oluşturur.

Uygun endikasyonu olan hastalarda önerilen cerrahi yöntem, proksimal femoral valgus osteotomisidir. Intertrokanterik ya da subtokanterik bölgeden uygulanabilecek farklı osteotomiler ve tespit yöntemleri tanımlanmıştır. (Peuwel'in intertrokanterik ' $Y$ ' şekilli osteotomisi[17], subtrokanterik uç-yan valgus osteotomisi[18] $)$. Tespit yöntemi olarak; eksternal fiksatörler, plaklar (kamalı plak, sabit açılı kilitli plak) ya da K-telleri kullanılabilir. ${ }^{[19]}$

Cerrahi sırasında yapılacak olan adduktor tenoto$\mathrm{mi}$, osteotomi bölgesinin valgusa alınmasını ve cerrahi sonrası dönemde kalça abduksiyonunu kolaylaştıracaktır. Osteotomi bölgesinde yapılacak kısaltma, 



Şekil 5. a-c. Dokuz yaşında erkek hasta. Spondiloepifizyel displazi. Femur boyun ve epifiz bölgesinde ossifikasyonda gecikme ve koksa vara deformitesi olan hastada Hilgenreinertrokanterik açının ölçümü (a). Aynı hastada pelvis MR görüntülemede femur boyun-baş ilişkisi görülmekte (b). Aynı hastanın bilateral proksimal femur valgus osteotomisi ve trokanterik apofizyodez sonrası 6 . ay takip filmi (c). düzeltmeyi kolaylaştıracak ve baş üzerinde oluşacak kuvvetleri azaltacaktır.[20] Proksimal femur büyüme plağı ve epifizi, pediatrik koksa vara deformitesinin düzeltilmesi sırasında çeşitli fiksasyon sorunları ortaya çıkarabilir. Uygulanan tespit yönteminin büyüme plağına zarar vermesi kalıcı hasara neden olabilir. Bunun yanında, tespitin epifizi içine alması fiksasyon kurvetini arttıracaktır. Kemik kalitesinin iyi olmadığı ve sağlam bir tespit sağlamanın zaten zor olduğu iskelet displazisi hastalarında büyüme plağına en az hasarı vererek sağlanacak epifizyel tespit, fiksasyon kalitesini arttıracaktır (Şekil 5c).

Yapılan valgus osteotomisi ile ilgili temel sorunlardan biri, varus deformitesinin tekrarlamasıdır. Amstutz ve ark. deformite tekrarı için en temel risk faktörü olarak yaşı öne sürseler de, cerrahi sırasında elde edilen düzeltmenin daha anlamlı bir belirteç olduğunu ortaya koyan çalışmacılar da olmuştur. ${ }^{[16,21]}$ Carrol ve ark., tekrarlama riskinin yaştan bağımsız olduğunu ortaya koyarken, radyolojik parametre olarak HEA'nın femur boyun - cisim açısına göre daha güvenilir olduğunu tespit etmişler; yaptıkları çalışmada, HEA'nın $38^{\circ}$ 'nin altına indiği hastalarda deformitenin tekrarlamadığını bulmuşlardır. ${ }^{[16]}$ Başka bir çalışmada bu değer $45^{\circ}$ olarak tespit edilmiştir. ${ }^{[22]}$ Literatürde, iskelet displazisi zemininde gelişen koksa vara deformitesi tedavisiyle ilgili uzun takipli geniş seriler bulunmamakla beraber, düzeltme sırasındaki yaşın ve düzeltme miktarının deformitenin tekrarlaması üzerinde etkili olduğu düşünülmektedir.

\section{TOTAL KALÇA PROTEZi}

Beklenen yaşam ömrünün uzamasıyla birlikte, kalça çevresinde ortaya çıkan patolojilerin kalça osteoartritine neden olma riski artmaktadır. Femur başı şeklinin bozuk olması, kısa ve varus deformitesine sahip femur boynu ve bunlara eşlik eden kalça çevresi yumuşak doku kontraktürleri, osteortrit gelişimine zemin hazırlar. Total kalça protezi endikasyonunu, normal popülasyonda olduğu gibi konservatif tedavi yöntemlerine cevap vermeyen ağıı ve eşlik eden hareket kısıtıııkları oluşturur.

Kalça çevresindeki kontraktürler, proksimal femur ve asetabulum morfolojisindeki farklılıklar nedeniyle, total kalça protezi uygulamaları sırasında farklı cerrahi tekniklerin ya da özel yapılmış protez bileşenlerinin kullanılması gerekebilir. ${ }^{[23]}$ Diastrofik displazili hastalarda yapılan total kalça protezinin sonuçlarının sunulduğu bir çalışmada; femoral kısaltma, trokanter majorün distale taşınması; adduktor, rektus femoris ve sartorius kaslarının gevşetilmesi; asetabulum çatısında ve mediyal duvarda greftleme yöntemlerine ihtiyaç 
duyulabildiği belirtilmiştir. Yine başka bir çalışmada ${ }^{[24]}$, proksimal femoral deformitelerin eşzamanlı düzeltilmesi amacıyla osteotomilerin gerekli olabileceği belirtilmiştir. Kalça sorunları erken dönemde ortaya çıkan ve protez ihtiyacı doğan bu hasta grubunda, beklenen yaşam ömrünün de uzamasıyla protezin sağkalımı ile ilgili sorunlar tartışma konusu olsa da, medikal tedaviye cevap vermeyen ve hastanın günlük hayat kalitesini ileri derecede etkileyen dejeneratif kalça varlığında, teknik zorluklarına rağmen total kalça protezi akılda tutulması gereken bir uygulamadır.

\section{KAYNAKLAR}

1. White KK, Sousa T. Mucopolysaccharide disorders in orthopaedic surgery. J Am Acad Orthop Surg 2013;21(1):1222. Crossref

2. Basset GS. Orthopaedic aspects of skeletal dysplasias. In: Greene WB, editor. Instructional Course Lectures, XXXIX. Park Ridge, IL: American Academy of Orthopaedic Surgeons; 1990. p.381-7.

3. Basset GS. Lower extremity abnormalities in dwarfing conditions. In: Greene WB, editor. Instructional Course Lectures, XXXIX. Park Ridge, IL: American Academy of Orthopaedic Surgeons; 1990. p.389-97.

4. White KK, Jester A, Bache CE, Harmatz PR, Shediac R, Thacker MM, Mackenzie WG. Orthopedic management of the extremities in patients with Morquio A syndrome. J Child Orthop 2014;8(4):295-304. Crossref

5. Tomatsu S, Alméciga-Díaz CJ, Montaño AM, Yabe H, Tanaka A, Dung VC, Giugliani R, Kubaski F, Mason RW, Yasuda E, Sawamoto K, Mackenzie W, Suzuki Y, Orii KE, Barrera LA, Sly WS, Orii T. Therapies for the bone in mucopolysaccharidoses. Mol Genet Metab 2015;114(2):94-109. Crossref

6. Langereis EJ, den Os MM, Breen C, Jones SA, Knaven OC, Mercer J, Miller WP, Kelly PM, Kennedy J, Ketterl TG, O'Meara A, Orchard PJ, Lund TC, van Rijn RR, Sakkers RJ, White KK, Wijburg FA. Progression of Hip Dysplasia in Mucopolysaccharidosis Type I Hurler After Successful Hematopoietic Stem Cell Transplantation. J Bone Joint Surg Am 2016;98(5):386-95. Crossref

7. Borowski A, Thacker MM, Mackenzie WG, Littleton AG, Grissom L. The use of computed tomography to assess acetabular morphology in Morquio-Brailsford syndrome. J Pediatr Orthop 2007;27(8):893-7. Crossref

8. Kennedy J, Noel J, O'Meara A, Mulhall K, Crushell E, Fogarty E, Kelly P. A Long-term Retrospective Evaluation of Functional and Radiographic Outcomes of Pediatric Hip Surgery in Hurler Syndrome. J Pediatr Orthop 2016;36(1):25-8. Crossref
9. Thawrani DP, Walker K, Polgreen LE, Tolar J, Orchard PJ. Hip dysplasia in patients with Hurler syndrome (mucopolysaccharidosis type $1 \mathrm{H}$ ). J Pediatr Orthop 2013;33(6):635-43. Crossref

10. Field RE, Buchanan JA, Copplemans MG, Aichroth PM. Bone-marrow transplantation in Hurler's syndrome. Effect on skeletal development. J Bone Joint Surg Br 1994;76(6):975-81.

11. Dhawale AA, Thacker MM, Belthur MV, Rogers K, Bober MB, Mackenzie WG. The lower extremity in Morquio syndrome. J Pediatr Orthop 2012;32(5):534-40. Crossref

12. Sponer $P$, Karpas $K$, Cenèk J. Surgical treatment of multiple epiphyseal dysplasia in the hip joints in childhood -short-term results. Acta Chir Orthop Traumatol Cech 2003;70(4):243-7.

13. Hefti F. Pediatric Orthopaedics in Practice, 2nd Edition. Berlin, Heidelberg: Springer-Verlag; 2015. p.202-3. Crossref

14. Trigui M, Pannier S, Finidori G, Padovani JP, Glorion C. Coxa vara in chondrodysplasia: prognosis study of 35 hips in 19 children. J Pediatr Orthop 2008;28(6):599-606. Crossref

15. Günther CM, Komm M, Jansson V, Heimkes B. Midterm results after subtrochanteric end-to-side valgization osteotomy in severe infantile coxa vara. J Pediatr Orthop 2013;33(4):353-60. Crossref

16. Carroll K, Coleman S, Stevens PM. Coxa vara: surgical outcomes of valgus osteotomies. J Pediatr Orthop 1997; 17(2):220-4.

17. Cordes S, Dickens DR, Cole WG Correction of coxa vara in childhood. The use of Pauwels' Y-shaped osteotomy. J Bone Joint Surg Br 1991;73(1):3-6.

18. Borden J, Spencer GE Jr, Herndon CH. Treatment of coxa vara in children by means of a modified osteotomy. J Bone Joint Surg Am 1966;48(6):1106-10.

19. Widmann RF, Hresko MT, Kasser JR, Millis MB. Wagner multiple K-wire osteosynthesis to correct coxa vara in the young child: experience with a versatile 'tailor-made' high angle blade plate equivalent. J Pediatr Orthop B 2001;10(1):43-50.

20. Skaggs DL, DuBois B, Kay RM, Hale JM, Tolo VT. A simplified valgus osteotomy of the proximal femur in children. J Pediatr Orthop B 2000;9(2):114-8.

21. Amstutz HC, Wilson PD Jr. Dysgenesis of the proximal femur (coxa vara) and its surgical management. J Bone Joint Surg Am 1962;44-A:1-24.

22. Cordes $S$, Dickens DR, Cole WG. Correction of coxa vara in childhood. J Bone Joint Surg Br 1991;73(1):3-6.

23. Helenius I, Remes V, Tallroth K, Peltonen J, Poussa M, Paavilainen T. Total hip arthroplasty in diastrophic dysplasia. J Bone Joint Surg Am 2003;85-A(3):441-7.

24. Peltonen JI, Hoikka V, Poussa M, Paavilainen T, Kaitila I. Cementless hip arthroplasty in diastrophic dysplasia. J Arthroplasty 1992;7 Suppl:369-76. 